\title{
The Use of Land in Master Plans of Towns from the Point of View of Sustainable Spatial Development
}

\author{
Liucijus Dringelis, Evaldas Ramanauskas and Giedrè Gudzinevičiūtė
}

Kaunas University of Technology, Institute of Architecture and Construction

crossref http://dx.doi.org/10.5755/j01.erem.58.4.677

(received in September, 2011, accepted in December, 2011)

\begin{abstract}
Rational use and protection of land depend to a considerable degree on territorial planning documents, especially on municipality general plans which contain definitions of land use objective, character and type. National policy results depend on the quality of these documents. One of the most important territories planning objectives stated in the law on the Territorial Planning is: save, use rationally and restore natural resources; create healthy and harmonious environment for life, work and rest; form natural frame, save and support balance of landscape ecological systems, etc. Nevertheless, in preparing municipality general plans these objectives are frequently ignored -urbanization is planned in valuable strategic objectives of sustainable development (Dèl nacionalinès darnaus... 2009) say: harmonize natural territories, slopes and waterfronts, construction of dwelling houses is legitimated on farmlands, need for public, recreational spaces and greenery is ignored, etc. Estimating such experience of preparation of master plans, it can be said that these solutions mostly fall short of the requirements for sustainable spatial development aspects - social, economical, ecological. Seeking better care and more rational use of land - the greatest country wealth, it is necessary to fortify the administration of this field at both levels - national (Ministry of Environment) and local (Municipalities of cities and regions). This actuality should be better reflected in the laws and the system of standards.
\end{abstract}

Keywords: sustainable development, territory planning, master plans, urban sprawl, land use.

\section{Introduction}

Overall environmental, economic and social development ensures clean and healthy environment, efficient use of natural resources, global economic well-being of society, strong social guarantees, etc. This is very clearly expressed in territorial planning activities. During this process, it is sought to provide and regulate the ways of fully sustainable urban development taking into account many factors. Rational use and protection of land resources (including open space) depend to a considerable degree on territorial planning documents, especially on municipality general plans containing the definitions of purpose, character and type. National policy results depend on the quality of these documents.

Today, changes in urban form and content are often referred to the questions of sustainable development. They are solved by urban sprawl, urbanization management, natural environment conservation, population decline or growth and its concentration. Cities are involved in intense international cooperation and development of mutual relations in political space. Many countries are now trying to adapt all of these changes to the requirements of sustainable urban development.

Analysis of this question is not new, especially among architect planners. Sustainable development principles are analyzed and emphasized in their practical and research work. Nevertheless, their good intentions do not always get the required shape and yield a desired result. In response to the situation, existing financial resources, public desires, private property, finally, the imperfection of the laws on the reservation are not always linked with the sustainable development principles. All these problems are studied not only by individual researchers and 
practitioners, but they are also dealt with in various events and conferences organized on sustainable environment and urban development (Darnioji plètra..., 2008). P. Juškevičius, Z. Daunora and the others go deep into the issues of urban planning. D. Bardauskiene studies the connections of territorial planning and sustainable development, their realization opportunities. J. Bučas analyzes composite questions of urban sprawl. Perspectives of agricultural, agrarian areas under the conditions of new economy are explored by P. Aleknavicius. J. Zagorskis analyzes the problems of implementation of a compact city. M. Pakalnis - improvement of the law system.

The aim of this article is to show the use of land in the preparation process of master plans of towns in the context of sustainable development. To disclose the situation objectively, the law requirements and specific cities examples of both planned and spontaneous development are given. The article is prepared on the basis of the research done on towns and their development areas in the KUT Institute of Architecture and Construction, the Centre of Territory Planning.

To determine the conservation of land as a resource and to find the means to achieve it, a few definitions are appropriate to be given:

Land - land and territorial waters owned by the Republic of Lithuania (LR Žemès..., 2004).

Territory planning - procedure laid down in the common area of development of spatial concepts, land use priorities, environmental protection, heritage preservation, and other set conditions to form land, water and forest, residential areas, manufacturing and infrastructure systems, to regulate population employment, to set the rights of physical and juridical persons activities in the territory (LR Teritorijų..., 2004).

Territorial planning documents - master (general), special and detailed plans, that in written and graphic forms give solutions for territories, land plots or their groups, show conditions how to manage, use, preserve and develop them (LR Teritorijų..., 2004).

General land planning - comprehensive planning for territory spatial development policy, to establish land use, conservation priorities and management measures (LR Teritorijų... 2004).

Master plan - a complex spatial planning document in which according to the planning level and challenges the planned development area and the spatial concept of land use and conservation principles are given. This is state or territory of the region comprehensive planning document in which, according to the planning level and challenges, the planned development area and the spatial concept of land use, conservation principles are known as the master (general) plan (LR Teritorijų... 2004).

\section{Master plans of towns - documents of land use and resource management}

The most important purposes of territories planning stated in the law on the Territorial Planning are: save, rationally use and restore natural resources; create healthy and harmonious environment for life, work and rest; form natural frame; save and support the balance of landscape ecological systems, etc. All of this defines lands, as limited quantitative and qualitative resource for use, conservation, restoration and regulation of these activities.

According to the regulations, land use is allotted by master (general), special and detailed planning. Master planning might be the subject of the national territory, or its parts - region, municipality, city or town territory. Master plans are prepared in accordance with the rules of master plans of various levels. These rules for cities and towns territories regulate preparation, approval and validity of master plans.

One of the main objectives of the master plans of cities and towns is to find solutions for determining the land use purpose. The main land use is determined according to the natural features of the area, traditional human activities, social and economic development needs and other factors. Preparing master plans of towns, it is sought to estimate the existing land use purpose and to provide a new one, which is needed to develop the existing urban structure and to create new areas for building and for public needs. The purpose of the land use provided in the master plan and in subsequent planning documents renders concrete expression to the method and character of the land plot use, there the activities allowed to be performed are specified. The purpose of the main land use is regulated by the law.

According to the main purpose of land use all the land of the Republic of Lithuania is divided into groups and types. The main groups of land use purpose are:

- agricultural land (amateurish and specialized gardens, recreational use land, etc.);

- forest land (protective, recreational, economic forests);

- $\quad$ water land (multi-purpose water reservoirs);

- conservation land (nature reservations, objects of cultural heritage);

- other land (residential, public, industrial and warehousing, commercial facilities, infrastructure, general use, mineral resources, recreation, national security, waste storage areas).

According to the law of the land, land owners and users must use the land according to its purpose and type, and must use it rationally, save land, forest, water, mineral, recreational and other natural resources. General areas of planning policy directions are defined by the Parliament, the Government forms the policy of state territory planning and determines the measures to implement it, the Ministry of Environment and municipalities implement this policy 
by preparing territorial planning documents. Despite this policy, a lot depends on the communities, land owners and users who complain about planning documents.

In general, the strategy of sustainable development in the field of territorial planning seeks to ensure equal development of country economics, social infrastructure, environment quality throughout the territory of Lithuania.

It can be seen that the master planning objectives are consistent with sustainable development principles, but in reality master plans often do not achieve these principles.

\section{The use of land in solutions of towns master plans}

Since the mid-twentieth century European towns have expanded on the average about $78 \%$, while the population increased only $33 \%$. Most of these trends are the consequences that European cities have become less compact. Densely populated, compact urban areas were modified by freely standing apartment houses, private houses. Thus, in many regions of Europe as well as in Lithuania the urban areas are still growing despite a decrease in population (Urban sprawl... 2006).

Urban development consists of a number of factors - demographic changes, economic aspects, transport development, planning regulatory delicacy. Low agricultural land prices in comparison with the price of the other land are also an important factor that accompanies urban development. A direct influence of these factors, namely, low prices and neglect of future territory use are clearly reflected in the growth of the blocks of private houses close to towns. The worst thing is that the authors of master plans are under some kind of pressure from the organizers and the community, in this way the opportunities for unreasonable or excessive development of the territory are created.

To determine the method of application of sustainable development principles to the development of towns in master plans, Kaunas town and Kaunas district are taken as example to show the experience in the master plans preparation. Development of Kaunas and its district, analysis of urbanized areas and their layout may to some extent reflect the process of urbanization trends in all other areas of the country.

In addition to Kaunas town and district planning documents, analysis of smaller towns and urban areas master plans is also given. Development of the territories is analyzed - they are often several times larger than there is a need because their population is decreasing.

From given Tables 1 and 2 it can be seen that the population in Kaunas town in the period of 2005 2010 has decreased by 15435 persons (or $4.24 \%$ ), but in Kaunas district at the same time it has increased by 5627 persons (or $6.24 \%$ ). This shows that the urban area population is decreasing, town is thinning out, but in suburban areas, urban zones are expanding and adopting agricultural land, forests, recreational areas.

Poorly controlled development of urbanized areas is essentially caused by the current planning system. If there are no prepared master plans, possibilities to develop specific areas are gained using special or detailed planning documents. Master plans also do not ensure the consistent growth of towns, because only following the current land market situation large urbanized territories often are planned (Ramanauskas 2009).

The gaps in the rules of territorial planning documents are noticed to allow the sprawl and urban unfounded territorial development by circumventing town master plan documents. In Kaunas district, which is territorially closest to the town, this is done by making use of another territory planning tool special planning. The result is straggling approaches to the town, legally organized urbanization of natural areas. Up to 2008, when Kaunas district master plan was prepared, special planning documents were intensively organized with one reason - to convert natural, agricultural land territories into the urban ones. The biggest urban development of Kaunas resulted in two phases of prepared planning documents: special plans (prepared since 2004, while there were no master plans) and Kaunas district master plan, prepared in 2008 (LR Teritorijų..., 2004).

The territories of Kaunas town on the Kaunas district land are shown in Figure 1. It can be seen that the main development ring emerged near the town border after intensive territorial development.

Table 1. Population change in Kaunas town and Kaunas district (Lietuvos statistikos..., 2010)

\begin{tabular}{|l|c|c|c|c|c|c||}
\hline \hline Territory & $\mathbf{2 0 0 5}$ & $\mathbf{2 0 0 6}$ & $\mathbf{2 0 0 7}$ & $\mathbf{2 0 0 8}$ & $\mathbf{2 0 0 9}$ & $\mathbf{2 0 1 0}$ \\
\hline Kaunas town & 364059 & 360637 & 358111 & 355586 & 352279 & 348624 \\
\hline Kaunas district & 84569 & 85100 & 85721 & 86701 & 88666 & 90196 \\
\hline All: & 448628 & 445737 & 443832 & 442287 & 440945 & 438820 \\
\hline
\end{tabular}

Table 2.

Population density in Kaunas town and Kaunas district (persons $/ \mathrm{km}^{2}$ ) (Lietuvos statistikos..., 2010)

\begin{tabular}{||l|c|c|c|c|c|c||}
\hline \hline Territory & $\mathbf{2 0 0 5}$ & $\mathbf{2 0 0 6}$ & $\mathbf{2 0 0 7}$ & $\mathbf{2 0 0 8}$ & $\mathbf{2 0 0 9} \mathbf{~ m}$ & $\mathbf{2 0 1 0 .}$ \\
\hline Kaunas town & 2318,8 & 2297,1 & 2281,0 & 2264,9 & 2243,8 & 2220,5 \\
\hline Kaunas district & 56,5 & 56,9 & 57,3 & 58 & 59,3 & 60,3 \\
\hline All: & 2375,3 & 2354,0 & 2338,3 & 2322,9 & 2303,1 & 2281 \\
\hline
\end{tabular}




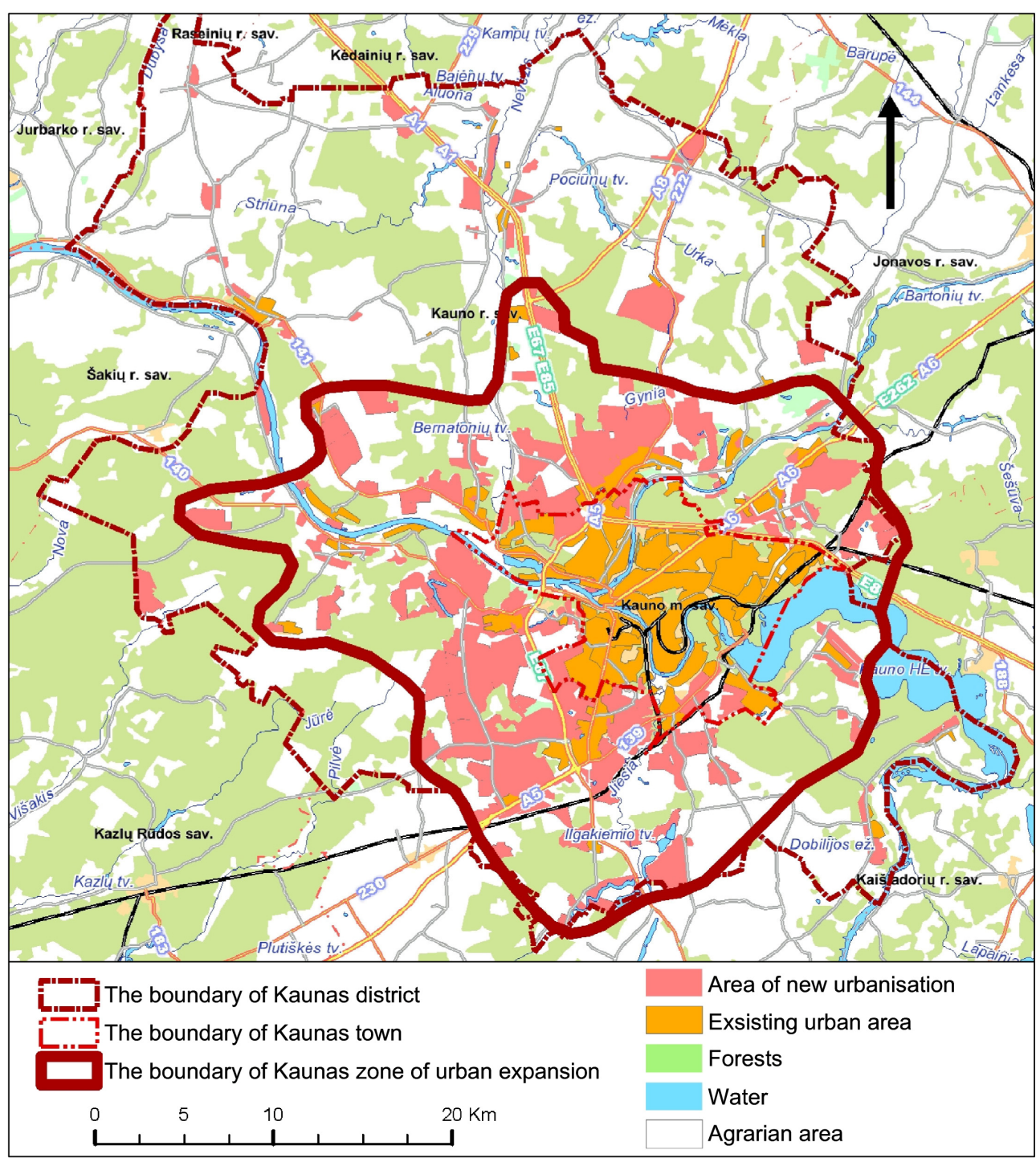

Fig. 1. The planned expansion of the urban areas of Kaunas town during the period of 2004-2009. (Scheme done according to: the monitoring information of planning development (from the Urban Department of Kaunas Municipality), Master plan of Kaunas town 2003, Master plan of Kaunas district 2008, topography Hnit-Baltic, www.maps.lt) (Kauno rajono..., 2008; Kauno miesto..., 2003)

Table 3.

Technical indicators of existing and planned territories of Kaunas town within its development zone (A)

\begin{tabular}{|l|c|c|}
\hline \multirow{2}{*}{ Territory } & \multicolumn{2}{|c|}{ Area } \\
\cline { 2 - 3 } & $\mathbf{k m}^{\mathbf{2}}$ & $\mathbf{\%}$ \\
\hline Kaunas town within its development zone & 800 & 100 \\
\hline Kaunas town & 160 & 20 \\
\hline Development zone & 640 & 80 \\
\hline Currently built up town within its development zone territory & 120 & 15 \\
\hline Planned to build up new territories in development zone & 130 & 16 \\
\hline Other territories (roads, forests, water and other) & 400 & 50 \\
\hline Not planned agricultural land & 150 & 19 \\
\hline
\end{tabular}

Table 4

Technical indicators of existing and planned territories of Kaunas town within its development zone (B)

\begin{tabular}{|c|c|c|}
\hline \multirow{2}{*}{ Territory } & \multicolumn{2}{|c|}{ Area } \\
\cline { 2 - 3 } & $\mathbf{k m}^{\mathbf{2}}$ & $\mathbf{\%}$ \\
\hline Kaunas town & 160 & 100 \\
\hline Built up Kaunas town territories & 90 & 56 \\
\hline Planned to build up in Kaunas town & 15 & 10 \\
\hline Development zone & 640 & 100 \\
\hline Built up area outside Kaunas town & 35 & 5 \\
\hline Planned to build up outside Kaunas town & 115 & 18 \\
\hline
\end{tabular}




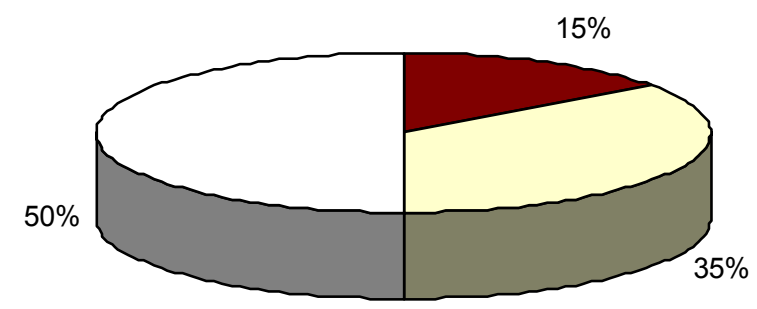

\begin{tabular}{|l|}
\hline The existing urbanised area \\
$\square$ The existing non urbanised \\
agrarian area \\
$\square$ Non constructional area (forests, \\
w ater, roads, etc.)
\end{tabular}

Fig. 2.

The proportion of existing urban and agrarian areas in Kaunas zone of urban expansion before the start of urban expansion in 2004

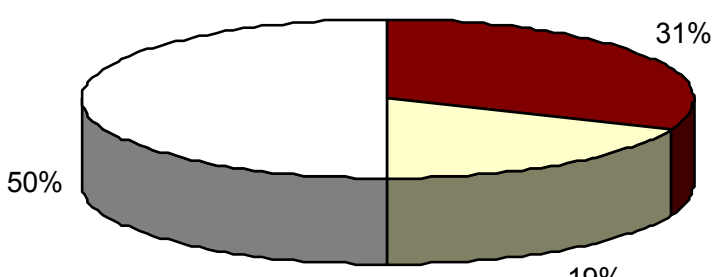

The existing urbanised and planned urban area

$\square$ The remaining non urbanised agrarian area

$\square$ Non constructional area (forests, w ater, roads, etc.)

Fig. 3. The proportion of urban and remaining agrarian areas in Kaunas zone of urban expansion in 2009. The twice growth of urban area is the result of detailed, special and master plans in Kaunas town and Kaunas district

When the Kaunas district master plan was prepared, new urbanized territories were planned. It is important to notice that reasonable planning of a lot of areas is obstructed by earlier accidentally made solutions of special and detailed plans (especially for development of transport, engineering, infrastructure systems, formation of green structure, etc)). Now, together with Kaunas town, they form the Kaunas town development zone. This zone takes in the territories as far as $10 \mathrm{~km}$, including small towns, agricultural land, forests and other natural areas.

The marked out urban core development zone is $800 \mathrm{~km}^{2}$. In this zone the urbanized territory is more than two and a half times larger than the present built up territory in Kaunas town. Compared to the whole Kaunas town area, it has become twice bigger.

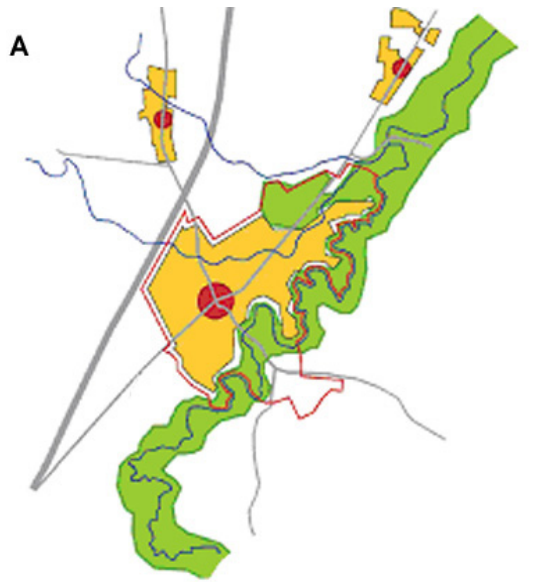

A lot of towns and districts can be given as similar examples. In Kelme town the population is decreasing like all over Lithuania. During 2001-2006 the population decreased by $3.6 \%$. A gradually growing town occupied a compact territory. But when preparing the last (2008) master plan of Kelmé, its area for built up territories was enlarged several times (Figure 4) (Kelmès miesto..., 2008). Undoubtedly, there were political and personal whims of maximizing the opportunities to develop housing solutions. However, in spite of the principles of sustainable development, the effective land use and preservation of land resources, the legally-based development of scattered houses or groups of them was regulated. It was done on the score of agricultural land and valuable natural areas.

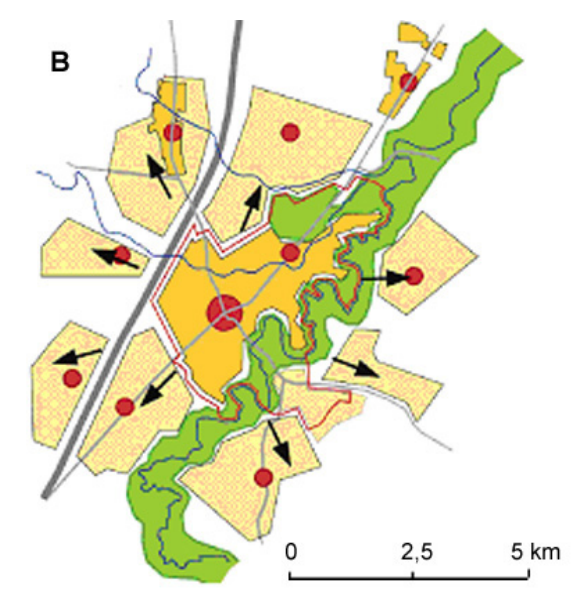

Fig.4. Groundless urban expansion of towns. The expansion of a new urban area of Kelme town. The planned urban expansion area four times exceeds the present urban area. A-present situation of Kelme town, $B$ - the proposals of municipality general plan of Kelme for 2007-2017. (Scheme is done according to master plan of Kelme town, 2007). (Kelmès miesto... 2008) 
Similar trends are observed in other towns and their outskirts. Unfortunately, it happens mostly in attractive natural areas and coastal areas such as Klaipeda town, Klaipeda district, Kretinga district, etc. (Figure 5).

From given examples it can be seen that in the current situation, master plans of towns, are not consistent with the principles of sustainable development trends. Loss of urban compactness, growth of urban sprawl is originally programmed for the future urban development problems. Such a situation is untenable.

Land use regulated by the master plans or lower special and detailed plans are often at odds with the sustainable spatial development principles and objectives.

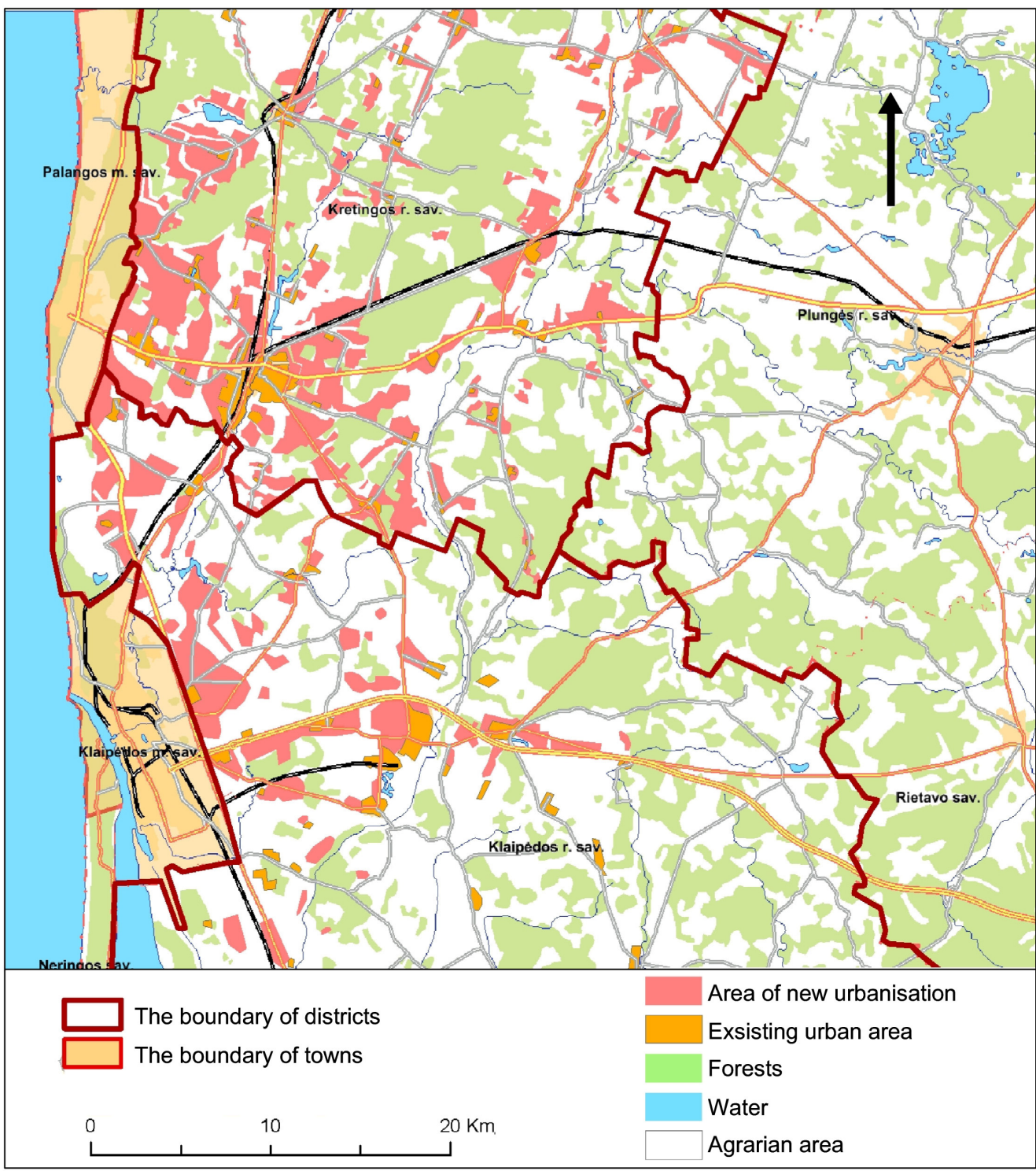

Fig.5.

The planned expansion of an urban area near the most important recreation area of Lithuania - the seacoast of the Baltic Sea. (Scheme done according to the master plan of Kretinga district (2008) and master plan of Klaipeda district (2005), topography Hnit-Baltic, www.maps.lt) (Kretingos rajono... 2008; Klaipédos rajono... 2005; Klaipédos rajono... 2010)

4. Valuation of land use in solution of master plans in the context of sustainable spatial development

On the basis of the analysis of towns master planning documents the expanded zones of urban areas can be assessed in terms of sustainable development. The criteria that could vividly demonstrate the development of new areas, their qualitative state are social, economic and ecological aspects.
The above mentioned analysis has shown that development of new urban areas, sometimes several times larger than the existing built-up ones, cause many social problems. First, because of the low population growth these sprawled structures have no real basis for solid compact residential areas which can locate public facilities. These planned areas usually have no public zones reserved for common use. Often they cannot appear simply because the master plans regulate generalized land-use content, and because there is a lack of expertise quality in 
urban planning solutions (Dringelis 2009). Society is one of the experts, which by law has the right to express their opinions, wishes and may seek to defend the general interest. However, these expectations are not always justified, as they often lie in the individual private speculative interests - the desire for greater personal gain regardless of the urban quality. It is difficult to regulate this, because there is no urban and landscape standards, and no impartial professional planning and evaluating quality institution.

Estimating urban development areas in economic aspects, first of all the serious damage done to agriculture is distinguished. Dispersed blocks break the rational agricultural land in separate, economically weak areas. Developing extensive built up areas, large plots of fertile land, the wealth of the country, are lost (Aleknavičius 2002; 2008). In this situation high economic costs are to ensure the engineering and maintenance of the infrastructure of these territories. In these areas of low building density there may be too few people to recoup the cost-supply infrastructure. Wide sprawled areas are located out of touch with social service and employment areas and they require high transport costs. Personal vehicle transport can be used there because of cost-based access there is no public transport. It has a negative impact on attractive recreation facilities and tourism development prospects.

New urbanized areas cause a number of environmental concerns. The completely urbanized urban areas quite often engulf sensitive natural environment primarily assigned for agriculture. The areas like the slopes, swampy - wet places, stream valleys often are allotted for the construction, sometimes even without evaluating them as nonconstructional areas (such as flood areas, slopes, etc.). In addition to the loss of ecological areas, there is no formation of an integrated natural green space within the new structure of development areas. There is no special system allotting parks, squares, green connections. Non-formed high-quality common areas lose the value of newly formed building land. These problems often arise in spatial development and due to them there are no real possibilities of redemption for these ecological environment lands.

Estimating such spatial development in the social, economic and ecological aspects, it can be said that new land areas are used irrationally, there are no possibilities for the development of high-quality engineering, transport and social infrastructure, thus, the ecological environmental situation is getting worse. Considering that due to changing economic circumstances the urbanization process may not occupy all the territories planned in this way, they will remain fragmented by individual buildings and their groups.

Urban development caused by various economic and demographic factors, social change, internal and external problems of towns and their regulation, forces specialists to rethink towns formation factors and their impact on residents and the environment. Many authors emphasize these problems, when talking about the difficulties of the master plans of Lithuanian towns, endless urban development and its problems (Tiškus 2007). According to P. Juškevičius "Lithuanian planning system does not possess the means to enable an objective assessment of social, economic and environmental interests in shaping the proportions of the dynamic processes of development, conservation efforts, private and public interests. This is the area for speculating the concepts of sustainable development". This is why Lithuanian towns are not growing according to the needs based on internal development but prefer the endless territorial expansion. To manage these complex processes, it is necessary to create effective juridical structures, taking part in the process of urban development and solving such questions in the long-term time.

As one of the main priorities for future urban development that in whole or partly reflects inner-city development is sustainable development. So far, sustainable development is not a universally popular feature of urban development. But it can be said that this is kind of globalization in the expression of an urban context and in people's minds - the world is widely sought for urban systems and their various aspects of ideality. Today a rare town can boast of having these sustainable development features, but towns are competing and looking for the ways to reach them and in this way to increase residential, tourist, investment and their other attractiveness.

Under the current prevailing conditions sustainability in the inner town development is a must. There are various ways of accomplishing it in accordance with the principles of sustainable development. Under different circumstances they may be selected for large or small, high or low level development of towns. Inner-city development making town territory denser can and should be applied to slowly growing towns. In that way, good conditions would be ensured to people to live in reasonably developed urban areas.

Seeking better care and more rational use of land, the greatest country wealth, it is necessary to fortify administration of this field at both national and local levels. The laws and the system of standards should clearly reflect it.

\section{Conclusions}

1. Land is the largest national resource, asset and its proper use must be the basis of rational public policy for control of a strong legal and regulatory framework, clearly preventing unreasonable urban land-use change to shortterm economic benefits.

2. Complex territorial planning projects - master plans are the main instruments that regulate the use of land resources. Therefore, suitable development of territories depends on the quality of master plans.

3. Currently Lithuanian population is decreasing whereas the urban areas are expanding by 
occupying new territories or planning their unreasonable development. It worsens the quality of urban living environment, depletes natural resources, and does not guarantee general welfare development.

4. As one of the most unreasonable planning facts is deficiency of organizational planning measures. Territory planning without urban norms and regulatory expertise often evolves into individual private interests.

5. Dispersed, fragmented urban areas reduce economic viability and attractiveness of agricultural, recreational areas. Their extensive use does not economically substantiate valuable, modern, social and engineering territorial supply.

6. Development of new areas often destroys valuable natural environment, disturbs the balance of natural frame. Green space system and living environment quality are not usually created reducing their economic value.

7. The main principles of sustainable environment stated in the main legal acts are not always implemented in practice. Therefore, the rational use of land resource and realization of sustainable development are obligatory keys of improving the legal framework for planning.

\section{References}

ALEKNAVIČIUS, P. Ar reguliuosime žemès ūkio paskirties žemės rinką? Žemès ūkis, Nr. 1, 2002.

ALEKNAVIČIUS, P. Žemès santykių pertvarkymas Lietuvos kaime 1989-2008 metais. Vilnius, Jandrija, 2008.

Darnioji plètra teritorijų planavime ir urbanistikoje. Vilnius, UAB „Petro ofsetas“, 2008.

Dèl nacionalinès darnaus vystymosi strategijos patvirtinimo ir igyvendinimo. Žin., 2009, Nr. 121-5215.

DRINGELIS L. Darnioji plètra teritorijų planavime ir jos reguliavimo galimybès. Pranešimas konferencijos „Subalansuotos plètros idèjų raiška architektūroje ir teritorijų planavime“ medžiagoje. Kaunas, Technologija, 2009.

JUŠKEVIČIUS P., Valeika V. 2007. Lietuvos miestu sistemų raida. Vilnius: Baltijos kopija.

Kauno miesto savivaldybės bendrasis planas. SI „Kauno planas“, projekto vadovas S. Lukošius, 2003. [Interaktyvus, žiūrèta 2009.04.05. http://www.kaunoplanas.lt/bendrieji planai/kauno miesto bendrasis planas 0 ]

Kauno rajono savivaldybès bendrasis planas. SI „Kauno planas“, projekto vadovas A. Steponavičius, 2008. [Interaktyvus, žiūrèta 2009.03.19 http://www.krs.lt ]

Kelmès miesto bendrasis planas. KTU Architektūros ir statybos institutas, projekto vadovas L. Dringelis. Kaunas, 2008. [Interaktyvus, žiūrèta 2011.07.26 http://www.kelme.lt/Savivalda/Teritoriju-
planavimas/Bendrieji-planai/Kelmes-ir-Tytuvenumiestu-bendrieji-planai ]

Klaipėdos rajono savivaldybès bendrasis planas. Klaipédos universitetas Baltijos pajūrio aplinkos tyrimu ir planavimo institutas, projekto vadovas A. Murieka, 2005.

Klaipėdos rajono savivaldybės bendrasis planas. UAB „Urbanistika“, projekto vadovas L. Naujokaitis. Vilnius, 2010. [Interaktyvus, žiūrèta 2011.08.08 http://www.klaipedos-r.lt/?1t=1252479830 ]

Kretingos rajono savivaldybès bendrasis planas. Klaipédos universiteto Regioninio planavimo centras, projekto vadovas A. Murieka. Klaipeda, 2008. [Interaktyvus, žiūrèta 2011.08 .07 http://www.kretinga.lt/?q=node/318 ]

Lietuvos statistikos metraštis 2010. Statistikos departamentas. Vilnius, 2010. [Interaktyvus, žiūrèta 2011.07.20.

http://www.stat.gov.lt/uploads/metrastis/LSM_2010_Lt.pdf ] 21-617.

LR Teritorijų planavimo ịstatymas. Žin., 2004, Nr.

LR Žemès įstatymas. Žin., 2004, Nr. 28-868.

RAMANAUSKAS E. Teisinė žemės nuosavybès reikšmè teritorijų planavimui, In: Urbanistika ir architektūra, 33(2). Vilnius: Technika, 2009, p. 82-91.

TIŠKUS G. 2007. Urbanistinès plètros valstybinio valdymo problemos. Urbanistika ir architektūra. 31, 4.

Urban sprawl in Europe. The ignored challenge. European Environment Agency Report. No 10/2006.

Dr. Liucijus Dringelis - head of Territory Planning Center, KUT, the Institute of Architecture and Construction. Main research area: landscape architecture and planning of health resorts, planning of recreational and green areas, urban planning, land-use management, cultural heritage.

Address: $\quad$ Tunelio st. 60, 44405 Kaunas, Lithuania Tel.: $\quad 8-37-451372$

E-mail: $\quad$ krastotvarka@asi.lt

Dr. Evaldas Ramanauskas - junior researcher in Territory Planning Center, KUT Institute of Architecture and Construction.

Main research area: effectiveness of the planning documents, economic aspects of land resources in territory planning, public areas, town and country landscape.

Address: $\quad$ Tunelio st. 60, 44405 Kaunas, Lithuania

Tel.: $\quad$ 8-37-451372

E-mail: $\quad$ krastotvarka@asi.lt

Giedrè Gudzinevičiūtė - senior architect in Territory Planning Center, KUT, the Institute of Architecture and Construction.

Main research area: urban planning, land-use management, globalization.

Address: $\quad$ Tunelio st. 60, 44405 Kaunas, Lithuania Tel.: $\quad$ 8-37-451372

E-mail: $\quad$ krastotvarka@asi.lt 


\title{
Žemès ištekliụ naudojimas darnios erdvinès plètros aspektu, rengiant miestų bendruosius planus
}

\author{
Liucijus Dringelis, Evaldas Ramanauskas, Giedrè Gudzinevičiūtė
}

Architektūros ir statybos institutas, Kauno technologijos universitetas

(gauta 2011 m. rugsèjo mèn.; atiduota spaudai 2011 m. gruodžio mèn.)

Žemès išteklių tausojimas, racionalus jų naudojimas bei apsauga žymia dalimi priklauso nuo teritorijų planavimo dokumentų, ypač nuo miestų ir miestelių bendrujų planų, kuriuose numatomos tikslinès žemės naudojimo paskirtys, naudojimo būdai ir pobūdžiai. Nuo šių dokumentų sprendinių kokybès priklauso ir valstybès politikos šioje srityje darbo rezultatai. Pagal Teritoriju planavimo isstatymą, vienas svarbiausių teritorijų planavimo tikslų yra: saugoti, racionaliai naudoti ir atkurti gamtos išteklius; formuoti sveiką ir harmoningą gyvenamająa, darbo ir poilsio aplinką; formuoti gamtini karkasą, sudaryti prielaidas kraštovaizdžio ekologinei pusiausvyrai palaikyti arba jai atkurti ir kt. Tačiau rengiant miestų ir kitu gyvenamujų vietovių bendruosius planus gana dažnai su minètais tikslais prasilenkiama - numatomas urbanizavimas vertingų gamtinių teritorijų, šlaitų ir pakrančių, įteisinamas statybų ,išmètymas“ žemès ūkio paskirties teritorijose, neformuojamos viešojo naudojimo erdvės, rekreaciniai želdynai ir pan. Vertinant tokị miestų bendrujjų planų rengimo patyrimą darnios erdvinès plètros aspektais - socialiniu, ekonominiu bei ekologiniu - galima teigti, kad šių planavimo dokumentų sprendiniai daugeliu atvejų neišlaiko minètų reikalavimų. Siekiant gerinti didžiausio šalies turto - žemès tausojimą bei racionalų naudojimą būtina stiprinti šios srities administravimą tiek šalies mastu (Aplinkos ministerija), tiek vietos mastu (miestų ir rajonų savivaldybès). Taip pat šio klausimo aktualumas turètų daugiau atsispindèti ir ịstatyminèje bei normatyvinèje bazèje. 